It seems clear that in 1946 there was no immediate prospect of obtaining oil in sufficient quantity for use by industry or shipping in the Arctic. But if the further work envisaged by the post-war Five Year Plan has been carried out, the Nordvik deposits may now yield an appreciable quantity.

\title{
THE REINDEER INDUSTRY IN THE SOVIET ARCTIC
}

[In 1948 a book entitled Severnoye olenevodstvo [Reindeet breeding], ${ }^{1}$ edited by P. S. Zhigunov and F. A. Terent'yev, was published by the Ministry of Agriculture of the Russian Soviet Federal Socialist Republic. The fact that some 120,000 words are devoted to this arctic industry testifies sufficiently to its importance in the U.S.S.R., and the chapters cover reindeer anatorny and physiology, hygiene, fodder and pastures, breeding, illnesses, use in transport, farm buildings and installations, slaughter and preparation of products, dogs for reindeer herding, and protection against predatory animals. The editors of an English translation which it is hoped to complete in 1951 have called our attention to the following paragraphs in the Introduction as of general interest. The area called the "Far North" is defined in a paragraph here omitted, and is shown on the accompanying map.]

"Reindeer farming is the most important branch of husbandry in the Far North and in many of the most northern rayony ${ }^{2}$ it is the fundamental productive activity of the population. From reindeer farming the inhabitants of the

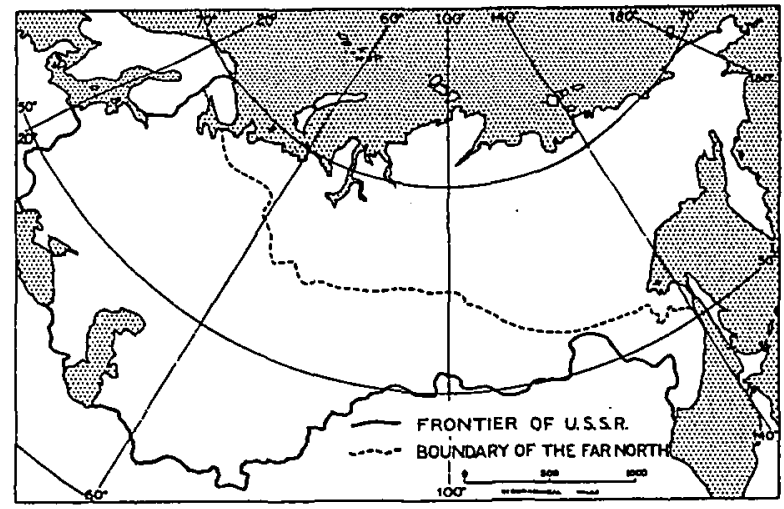

Map showing the area of the "Far North".

north get meat and fat for food, skins for making clothes and footwear and also for making dwellings (skin tents). Besides satisfying the inhabitants' requirements of food and various necessities of their daily life and work, reindeer farming provides the nomad population with a fundamental and, up to now, unique and irreplaceable means of travelling during their migrations and when hunting and transporting loads.

"Delivery of goods from ports and wharves to the consumer in the heart of tundra, forest tundra and taiga, and the transfer of the prepared raw material -meat, fish, hides, furs, etc.-from these inaccessible places is mainly carried out by reindeer transport. Tens of thousands of transport reindeer, hundreds and thousands of reindeer herdsmen are employed yearly on goods transport."

I Reviewed by T. E. Armstrong in the Geographical Journal, Vol. 113, 1949, p. 139-41.

2 An administrative area corresponding roughly to a county.-Eds. 
On the northern edges of Tyumenskaya Oblast', Krasnoyarskiy Kray, Yakutskaya A.S.S.R. and other rayony of the Far North, special reindeer pack. trails are organized. ${ }^{1}$ They are equipped with skin tents every $40-50 \mathrm{~km}$., provided with good pastures and in many cases with supplies of concentrated fodder for supplementary feeding of the transport reindeer. The length of thesepack trails is, as a rule, several hundred, but sometimes more than a thousand, kilometres.

"According to the figures in statements of accounts for reindeer collective farms for 1946, the income received from the use of reindeer for transport was, on the average for all rayony of the Far North, about $17 \%$ of the total income. Further, in some reindeer collective farms providing service and maintenance on the reindeer pack trails, the earnings from the use of reindeer for transport. were the principal source of revenue.

"Such an important branch of the northern economy as trapping is in direct dependence on the state and development of reindeer farming. Figures from the yearly accounts of collective farms for recent years show this.... The more reindeer the collective farm has, the more traps it has for Arctic Fox, the more opportunity it has of annexing to its use large expanses of trapping territory and consequently the greater the revenue from fur trapping.

"The importance of the reindeer is not limited by its usefulness as a transport animal or as a source of food, clothes and housing material for the native population. Reindeer hide, for example, when appropriately worked provides a high quality suedde of importance in the aviation, optical, precision instrument and footwear industries. From the skins of young reindeer beautiful light furs are made. Reindeer hair is used for making mattresses, and also for furniture and saddlery. Reindeer underwool, which is about $30 \%$ of a reindeer's total fur, is made into felt, knitted and other goods, which are remarkable for their warmth. The antlers which are cast yearly are suitable for making glue, gelatine and bone-ware articles.

"Reindeer breeding is a comparatively young branch of the national economy of the U.S.S.R. In Russia before the Revolution the reindeer was mainly looked on in literature as one of the furbearing animals. In such a state of public opinion, naturally, real veterinary and zootechnical ${ }^{2}$ help could not be provided for reindeer farms. Because of this, the epizootic diseases which raged every year destroyed tens and hundreds of thousands of reindeer. Deaths were registered only in Bol'shezemel'skaya Tundra $^{3}$ and there deaths caused by anthrax alone were: $1898-76,000 ; 1907-200,000 ; 1911-100 ; 000$. It was no better in other parts. The complete lack of organization of the areas for pasture, their excessive use, the almost yearly winter famine, the absence of any campaign against small insects or the gadfly [ovod] in summer hot spells, led to the general exhaustion and sickening of the reindeer, and eventually to their dying in large numbers. The reindeer death-rate approached their birth-rate and often even exceeded it. Consequently reindeer farming in Russia before the

1 The area designated covers much of the most northerly part of Asiatic Russia.-Eds.

2 Veterinary, but without full veterinary qualifications.-Eds.

3 In the north-eastern corner of Russia in Europe.-Eds. 
Revolution, far from developing, contracted year by year. Reindeer farming was only set on the right road for genuine development under the Soviet power and especially during the Stalin Five Year Plans.

"In the first years of the Stalin Five Year Plans over 120 zootechnical and veterinary stations and points for supplying reindeer farms with zootechnical and veterinary assistance were founded. A special network of scientific research institutes was established for the service and maintenance of reindeer farming. In $1930-40$ the whole territory of the Far North-10,000,000 sq.km.-was divided according to the laws governing distribution of land and water.

"The new Soviet socialist culture showed without delay its beneficial influence on the development of the whole national economy in the Far North, including reindeer farming. The rate of development of reindeer farming in all sectors of the economy of the Far North (in collective farms, State farms and peasant properties) for the years of the Stalin Five Year Plans, the period of the second world war and the post-war years, is shown by the following figures : ${ }^{1}$ $(1933=100) ; 1934,104 \cdot 2 ; 1935,110.5 ; 1936,117 ; 1937,122.9 ; 1938,128.1$; $1939,130.8 ; 1940,132 \cdot 4 ; 1941,133.3 ; 1942,123 \cdot 2 ; 1943,118.2 ; 1944,118 \cdot 8$; $1945,119 \cdot 8 ; 1946,129 \cdot 8$.

"From 1933, i.e. from the organization of reindeer collective farms and State farms in rayony of the Far North, reindeer farming has shown a steady growth. Only during the second world war did the stock fall sharply. This resulted from the smaller number of reindeer in the private use of collective farm workers, from the increased slaughter of reindeer on collective farms and State farms for meat for the Army, and finally from loss through inferior care of the herds, owing to the mobilization of many experienced herdsmen. But as early as 1944 reindeer farming was again on the upward path. In 1946 the stock had reached its pre-war level.

"The beneficent influence of the socialist economic system on the development of reindeer farming is shown even more clearly by the rate of growth of the reindeer herds on collective farms. ${ }^{2}$

"Reindeer farming in the U.S.S.R. has a great future. We have every possibility of increasing the head of reindeer in the Far North two and a half or three times over. According to the data of the botanical investigations made at the time of the original land and water distribution laws, there is reckoned to be enough pasture in rayony of the Far North for roughly 10,000,000 reindeer. The immediate task in the development of reindeer breeding is the extension of the veterinary network that serves the reindeer collective farms. The veterinary network for reindeer farms in rayony of the Far North is to be nearly doubled by the end of the first post-war Five Year Plan. Greater care of the herds by veterinary doctors and zootechnicians will allow better organization of the work in the herding teams on collective farms and State farms, and the more thorough and widespread carrying out of prophylactic veterinary measures, which will diminish the losses from various illnesses and mainly from the so-called hoof disease (necrobacillosis). No less serious a task is the more

1 Summarized from a Table.-Eds.

2 A Table shows this as being, in 1940, 550.8 \% of the 1933 figure, and in 1946, 883.3 \%.-Eds. 
consistent application of the land distribution laws on reindeer collective and State farms, and in particular the introduction of a proper rotation on the winter reindeer-moss pasture, which was not done under the original land and water distribution laws. The increase of technical equipment on reindeer collective farms and State farms and, in particular, the provision of essential farm buildings is of great importance for reindeer farming. In this connection the construction of new movable rope fences and stationary wooden corrals, and also of intermediate bases on the migration routes, is planned for the Far North in the next few years. Finally, among problems of first importance, the ultimate and decisive one is that of the training and retraining of reindeer herdsmen. Measures for training and retraining qualified herdsmen are carried out by the compulsory adoption of a system of apprenticeship in all collective farm and State farm herding teams and by organizing special seminaries and courses attached to the local agricultural bodies in rayony of the Far North. Besides this it is intended to increase the number of students and the length of the course in the present local schools, which are open all the year round for the training and retraining of specialist herdsmen.

"The carrying-out of these tasks, which guarantees the future development of reindeer farming in the U.S.S.R., will demand from the reindeer farm workers further strengthening of the economic organization of, above all, reindeer collective farms and State farms and an increase in their productivity (both absolutely and in the proportion of products marketed) and in their revenue. The fundamental condition of a successful fulfilment of the plans for developing reindeer farming is the scrupulous observance of Stalin's regulations for agricultural co-operatives as an unshakable law. Therefore the struggle against infringements and distortions of these regulations must be one of the fundamental economic and political tasks of the workers of rayony of the Far North."

\section{OUTBOARDENGINES USED BY THE CAMBRIDGE SPITSBERGEN EXPEDITION，1949}

[It is hoped that the following note, summarized from an unpublished report by $R$. $G$. Atkinson, will form a useful supplement to the note by P. S. B. Digby on small boats for use in Spitsbergen, published in the Polar Record, Vol. 5, No. 39, 1950, p. 467.]

The purpose of the report is to compare the relative merits of particular outboard engines from the experience gained during the Cambridge Spitsbergen Expedition in the summer of 1949.

In Norway the expedition had bought three boats; two new Norwegian clinker-built whalers, $16 \frac{1}{2} \mathrm{ft}$. long, known as Strandelbarmars, and an old 18-ft. dory, rather like a North Sea cobble, very heavy and with a transom stern. The Strandelbarmars were suitable for small parties and personal gear, but the dory was required for heavier expedition equipment.

As water was the most practical means of passage between the expedition's base, Longyearbyen, and the various camps, the boats were in constant use. Most of the trips were in fjords hemmed in by mountains about $3000 \mathrm{ft}$. (915 m.) 